\title{
Assessment of State and Trait Anxiety Level of Physical Education and Sports' Students before the Term Final Examinations: Example of Halic University
}

\author{
Cigdem Bulgan ${ }^{1, *}$, Hatice Ilhan Odabas ${ }^{1}$, Suzan Dal ${ }^{2}$, Elif Meçu ${ }^{1}$, Mensure Aydın ${ }^{3}$ \\ ${ }^{1}$ School of Physical Education and Sport, Halic University, Turkey \\ ${ }^{2}$ Faculty of Sport Sciences, Istanbul University, Turkey \\ ${ }^{3}$ Faculty of Sports Science, Kocaeli University, Turkey
}

Copyright $\bigcirc 2017$ by authors, all rights reserved. Authors agree that this article remains permanently open access under the terms of the Creative Commons Attribution License 4.0 International License

\begin{abstract}
The purpose of this study was to evaluation of state and trait anxiety levels of students in Halic University, School of Physical Education and Sports, during final exams according to their age, department and year in school. For this research, 469 students (mean age 21,17 $\pm 2,27$ ) studying in 2014-2015-spring term were chosen randomly. As data collection tools, personal information form and Spielberger's State-Trait Anxiety Inventory which consists of 40 questions; 20 to evaluate state anxiety and 20 for trait was used. Statistical analysis of the obtained data was evaluated by SPSS 20.0 Windows program with Frequency, T-Test and Anova Analysis. As a result of the research; state and trait anxiety of students in Halic University, School of Physical Education and Sports differed in few factors. The both levels were shown differences according to the year of the students studied $(\mathrm{p}<0.05)$. Based on years; first, second and third year students have higher state anxiety levels than fourth whereas for trait anxiety fourth year students have the highest level $(\mathrm{P}<0,05)$. In conclusion, students who were in graduate situation had more anxiety level than the others.
\end{abstract}

Keywords Anxiety, State, Trait, Physical Education, Sports and Student

\section{Introduction}

The root of the word anxiety is coming from ancient Greek "anxsietas", it means worry, fear, curiosity. It is a universal feeling and experience one goes through in certain states of his life. In general meaning, anxiety is defined by the experts as the fear or unsettling feeling one experience in a wake of a threatening event. The reaction one gives against a future unwanted event and an unconfident time expresses future anxiety, instability, chaos, fear, pessimism and hopelessness, therefore it results in failure $(6,10,2,1,21)$.

Anxiety is described in "state-trait" model. State anxiety derives from a time when one views or interprets a situation as threatening and dangerous. This situation results in an unsettling, unwanted state. When people view a situation as threatening they feel anxiety. If someone feels anxious in result of a threatening situation that worry is considered normal and temporary. On the contrary, trait anxiety is not directly related to a certain situation, but it reasons from one's own personality. Especially, when the stress is intense, anxiety level is getting high (27). The reactions to a state anxiety is listed as negative feelings such as; excitement, wakefulness, fear, misgiving, confusion, lack of self-confidence. Duration and intensity of the trait anxiety differs depending on personality structure. If someone has a tendency towards being anxious the level of trait anxiety increases. When faced with a situation that is threatening to one's self-confidence, people with higher trait anxiety levels compared to people with lower ones show much more trait anxiety reactions $(12,22,15)$.

The anxiety of the exams in school is a feeling of students experience through all their school lives. This feeling brings out situations such as; inability to get ready for an exam, excessive physical reactions because of lack of knowledge on efficient work tips, brain activity unrelated to exam (12, 2). If someone experiences high anxiety, the person is on the edge and tension causes veins to shrink and prevents blood from properly flowing into the cells. Adrenalin that is released under tension and anxiety prevents protein chain needed for learning from established. During tension and anxiety, cells are not able to use up the oxygen they need, therefore are unable to reach their full capacity (1). A student's academic achievements are important for himself, his family or the society he lives in. Unexpected academic failures, dropping out of school, inability of reaching one's potential contrast to his abilities leads preventing the needed 
amount and quality of labor force from joining to the society. While teacher candidates are preparing for 'Public Staff Selection Exam' (KPSS), they go through more anxiety than their first year when they reach their last year $(17,5,14)$. KPSS is an exam that was first introduced as civil service examination in 1999 and it is set to recruit public staff such as teacher, officer, police, soldier, doctor, engineer etc. As in most public establishment, when the ministry of education assigns the teachers they take this exam as standard (8).

Meanwhile, teacher candidates are trying to finish up" their majors, they also are desperately, anxiously and intensively getting ready to KPSS. This situation puts a very negative pressure on teacher candidates. Especially, teacher candidates who graduated or just about to be graduated have higher level of anxiety. Because KPSS is the final step for candidates to be recruited for the job they have been trained for. Therefore, candidates are under a lot of pressure and suffer from high anxiety (17). The reason why the study was done on this group was to learn how these students in the physical education and sports faculties (as regularly sporting individuals) were concerned about their state and trait concerns during their education. Recent studies have shown that athletes are less concerned about their academic performance while determining anxiety situations in the sportive performance. The purpose of this research was to evaluate state and trait anxiety levels of students in Halic University, School of Physical Education and Sport during the spring term final exams.

\section{Material and Methods}

\subsection{Research Model}

General scanning method was used for this research. Scanning method is an approach to define a past or current event as it is (9). It was planned to evaluate state-trait anxiety levels of students in Halic University, School of Physical Education and Sport. Therefore, the research was descriptive.

\subsection{Population and Sampling}

The population of the research was consisted of Halic University, School of Physical Education and Sports students. 469(400 men and 69 women) students were participated to this study during 2014-2015 spring education term.

\subsection{Measurement Tools}

As data collection tool in this research, personal information form and Spielberger's State-Trait Anxiety
Inventory were used. Spielberger's State-Trait Anxiety Inventory consists of two sub inventories with 20 articles for each; Trait Anxiety Inventory (TAI) and State Anxiety Inventory (SAI). Turkish validity and reliability study was applied by Öner (1997) (20). Correlation Coefficient was 0.34 to 0.72 for the Trait Anxiety Inventory; for the State Anxiety Scale; between 0.42 and 0.85 (Öner and Comte, 1983).

The scoring of inventory; the inventory has straight or reverse statements. Positive feelings, when the said reverse statements were scored the ones scored 1 is changed to 4 and the ones scored 4 is changed to 1 . When negative feeling are stated the score valued 4 means the anxiety is high. As for the reverse statements, 4 expresses low, 1 expresses high anxiety. For the total scores obtained from straight statements are reduced from reverse statements' total values and an unchanged amount is added to this number. The value came out of inventory changes between 20-80. High number is for high anxiety level and low is for low level (19).

Personal Information Form contains demographic data that could be related to the study and was determined by researchers.

\subsection{Statistical Analysis}

The data were analyzed with SPSS 20.0 (SPSS Inc., Chicago, IL, USA) program. To evaluate distribution of subjects in the sampling group by personal values, descriptive statistics such as; frequency, percent values, mean values, standard deviation were used. After comparing state-trait anxiety levels if it appears that variables contain more than two groups, One Way Anova was used. As a result of Anova; in the event of having differences between groups, to determine where the differences were coming from one of the multiple comparison tests Tukey HSD was used. Confidence interval was determined as $\% 95$ and the values under $\mathrm{p}<0.05$ were accepted as statistically significant.

\section{Results}

As a result of the study, state and trait anxiety scores of the students were found as $40,18 \pm 8,32$ for trait anxiety and $61,19 \pm 11,02$ for state anxiety. And Table 1 .shows state-trait anxiety differences of students according to the academic years.

When Table 1 examined, the trait anxiety level of students sorted by years, the fourth year students have statistically significantly higher anxiety level than first and third years students. When state anxiety levels examined fourth year students have statistically significantly less anxiety level than first, second and third years $(p<0.05)$, between the other years there were no significant differences found $(\mathrm{p}>0.05)$. 

before the Term Final Examinations: Example of Halic University

Table 1. Differences of State-Trait Anxiety Levels of Students by Their Academic Year.

\begin{tabular}{|c|c|c|c|c|}
\hline & Academic Years & Academic Years & Mean \pm Std Deviation & $P$ values \\
\hline \multirow{12}{*}{ Trait Anxiety Levels } & \multirow{3}{*}{$1^{\text {st }}$ year } & $2^{\text {nd }}$ year & $-1,17 \pm 0,87$ &, 538 \\
\hline & & $3^{\text {rd }}$ year & $1,61 \pm 1,30$ & ,602 \\
\hline & & $4^{\text {th }}$ year & $-3,45 \pm 1,24$ &, $030 *$ \\
\hline & \multirow{3}{*}{$2^{\text {nd }}$ year } & $1^{\text {st }}$ year & $1,17 \pm 0,87$ &, 538 \\
\hline & & $3^{\text {rd }}$ year & $2,79 \pm 1,35$ &, 168 \\
\hline & & $4^{\text {th }}$ year & $-2,27 \pm 1,29$ & ,297 \\
\hline & \multirow{3}{*}{$3^{\text {rd }}$ year } & $1^{\text {st }}$ year & $-1,61 \pm 1,30$ & 602 \\
\hline & & $2^{\text {nd }}$ year & $-2,79 \pm 1,35$ &, 168 \\
\hline & & $4^{\text {th }}$ year & $-5,06 \pm 1,61$ &, $010 *$ \\
\hline & \multirow{3}{*}{$4^{\text {th }}$ year } & $1^{\text {st }}$ year & $3,45 \pm 1,24$ &, $030 *$ \\
\hline & & $2^{\text {nd }}$ year & $2,27 \pm 1,29$ &, 297 \\
\hline & & $3^{\text {rd }}$ year & $5,06 \pm 1,61$ &, $010 *$ \\
\hline \multirow{12}{*}{ State Anxiety Level } & \multirow{3}{*}{$1^{\text {st }}$ year } & $2^{\text {nd }}$ year & $1,67 \pm 1,14$ & ,462 \\
\hline & & $3^{\text {rd }}$ year & $-, 58 \pm 1,70$ & ,986 \\
\hline & & $4^{\text {th }}$ year & $7,51 \pm 1,63$ &, $000 *$ \\
\hline & \multirow{3}{*}{$2^{\text {nd }}$ year } & $1^{\text {st }}$ year & $-1,67 \pm 1,14$ & ,462 \\
\hline & & $3^{\text {rd }}$ year & $-2,26 \pm 1,77$ &, 579 \\
\hline & & $4^{\text {th }}$ year & $5,84 \pm 1,69$ &, $004 *$ \\
\hline & \multirow{3}{*}{$3^{\text {rd }}$ year } & $1^{\text {st }}$ year & $0,58 \pm 1,70$ & ,986 \\
\hline & & $2^{\text {nd }}$ year & $2,26 \pm 1,77$ &, 579 \\
\hline & & $4^{\text {th }}$ year & $8,10 \pm 2,12$ &, $001 *$ \\
\hline & \multirow{3}{*}{$4^{\text {th }}$ year } & $1^{\text {st }}$ year & $-7,51 \pm 1,63$ &, $000 *$ \\
\hline & & $2^{\text {nd }}$ year & $-5,84 \pm 1,69$ &, $004 *$ \\
\hline & & $3^{\text {rd }}$ year & $-8,10 \pm 2,12$ &, $001 *$ \\
\hline
\end{tabular}

$* \mathrm{p}<0.05$

Table 2. shows state-trait anxiety differences of students according to their education department. According to the results there were no significant anxiety level differences between students' departments (Table 2).

Table 2. Differences of State-Trait Anxiety Levels of Students by Their Departments.

\begin{tabular}{|c|c|c|c|c|}
\hline & Department & Department & Mean \pm Std Deviation & $P$ values \\
\hline \multirow{6}{*}{ Trait Anxiety Levels } & \multirow{2}{*}{ Coaching } & Sports Management & $-0,30 \pm 0,84$ & ,930 \\
\hline & & Recreation & $1,77 \pm 1,10$ & ,243 \\
\hline & \multirow{2}{*}{ Sports Management } & Coaching & $0,30 \pm 0,84$ & ,930 \\
\hline & & Recreation & $2,08 \pm 1,13$ & 157 \\
\hline & \multirow{2}{*}{ Recreation } & Coaching & $-1,77 \pm 1,10$ &, 243 \\
\hline & & Sports Management & $-2,08 \pm 1,13$ &, 157 \\
\hline \multirow{6}{*}{ State Anxiety Level } & \multirow{2}{*}{ Coaching } & Sports Management & $0,44 \pm 1,11$ & ,916 \\
\hline & & Recreation & $-2,60 \pm 1,46$ &, 177 \\
\hline & \multirow{2}{*}{ Sports Management } & Coaching & $-, 44 \pm 1,11$ & ,916 \\
\hline & & Recreation & $-3,05 \pm 1,49$ &, 104 \\
\hline & \multirow{2}{*}{ Recreation } & Coaching & $2,60 \pm 1,46$ &, 177 \\
\hline & & Sports Management & $3,05 \pm 1,49$ & , 104 \\
\hline
\end{tabular}


Table 3. shows state-trait anxiety differences of students according to their ages. As a result, there was no significant anxiety level differences between students' ages found (Table 3).

Table 3. Differences of State-Trait Anxiety Levels of Students by Their Ages.

\begin{tabular}{|c|c|c|c|c|}
\hline & Age Ranges & Age Ranges & Mean \pm Std Deviation & $P$ values \\
\hline \multirow{6}{*}{ Trait Anxiety Levels } & \multirow{2}{*}{$17-19$} & $20-23$ & $-1,55 \pm 0,93$ &, 218 \\
\hline & & $24+$ & $-1,72 \pm 1,27$ &, 370 \\
\hline & \multirow{2}{*}{$20-23$} & $17-19$ & $1,55 \pm 0,93$ & ,218 \\
\hline & & $24+$ & $-0,16 \pm 1,11$ & ,988 \\
\hline & \multirow{2}{*}{$24+$} & $17-19$ & $1,72 \pm 1,27$ & ,370 \\
\hline & & $20-23$ & $0,16 \pm 1,11$ & ,988 \\
\hline \multirow{6}{*}{ State Anxiety Level } & \multirow{2}{*}{$17-19$} & $20-23$ & $2,79 \pm 1,23$ &, 063 \\
\hline & & $24+$ & $1,94 \pm 1,69$ & ,485 \\
\hline & \multirow{2}{*}{$20-23$} & $17-19$ & $-2,79 \pm 1,23$ &, 063 \\
\hline & & $24+$ & $-0,85 \pm 1,47$ &, 832 \\
\hline & \multirow{2}{*}{$24+$} & $17-19$ & $-1,94 \pm 1,69$ & ,485 \\
\hline & & $20-23$ & $0,85 \pm 1,47$ & ,832 \\
\hline
\end{tabular}

$* \mathrm{p}<0.05$

\section{Discussion}

The aim of the research was to evaluate if the state-trait anxiety levels of students in Halic University, School of Physical Education and Sports had any differences. It was conducted the $4^{\text {th }}$ year students were shown higher trait anxiety levels. The reason for this appears to be based on the fear; if they could make it to graduation or not or further to that a newly fear; whether they would be able to land a job or not.

Young people are faced with a society that emphasizes success in academic life and more competitive environment, especially in Turkey. The increase in the importance given to achievement has also raised the need for the evaluation of individuals. From a high school standpoint, it makes it more compulsory for students to enter the university and increases their test anxiety. With the increasing importance given to the university exam; the number of students experiencing anxiety of examination and the need for treatment of this anxiety type. The university exam is considered a 'threat' to the future by the students preparing for the exam, which causes both the cognitive and physiological effects of exam anxiety (Palti, 2012). The greatest anxiety of almost graduated students is to take the examination of KPSS in Turkey after graduation to having a proper job in public places. When KPSS is mentioned, the fact that teacher, coach and manager candidates think of "tiredness, distress and memurlar.net" is a crucial aspect. In order to get ready for KPSS, teacher candidates go into overdrive. Also, the fear and distress of not being able to get assigned considerably wears them out (17). Dinçer and Akdeniz determined that motivation; time management and exam anxiety has a significant effect on academically success of teacher candidates (12).

Gündoğar and colleagues (7) confirmed in their research that university students who had job expectations had also higher trait anxiety levels. Students with high trait anxiety levels also had less life satisfaction level. Şahin and colleagues (18) pointed out in their research that first year students had higher life satisfaction levels than last year students in the same major. This finding shows that whereas fourth years students had expectations that were not met throughout the years, the first year students have not yet had this kind of disappointment and still carry hopes of having met their expectations. The findings in our research also have been supporting to this evidence.

Kaya and Varol (10) explored in their study on the state-trait anxiety level of the students in faculty of theology was evaluated with regards to their grades, majors, genders, marital status, economics conditions, working conditions and academic standings. Anxiety levels showed great differences in view of majors, genders, marital status, economics conditions and working in a job or not. Students listed "sickness and loss of loved ones" and "being able to find a job or not" as their greatest source of anxiety. According to the results of the study on the students, some demographic factors such as gender have affected the students' anxiety levels (Mcknight and Mcknight, 2012). In the study of the relationship between anxiety and depression of 200 university students studying at different faculties; the anxiety levels of the female students found higher than male students (Lama M and Al-Qaisy, 2011). In a similar study; the relationship between state-trait anxiety and violence was examined in the self-efficacy feelings of students from psychology department. It concluded that the level of anxiety was higher in males than in females, as well as a negative 
relationship between state and trait anxiety (Rand and Poornaghi, 2012). In the study of the academic achievement and anxiety levels of first year biology students; it was found that there was a high level of state anxiety rather than trait anxiety (Remedios and Melanio 2013).

In their research on university students who suffer from future anxiety, Shanlı and his colleagues (11) suggested that trait anxiety while gender, faculty/school, parental attitude, monthly income of the family and residence variables and trait anxiety levels have statistically significant differences, in terms of university entrance date and cumulative grade point average there was no statistically significant difference. Yilmaz and et al. (21) in their research focused on determining anxiety levels of university students, they indicated that while socio-demographic feautures such as; monthly income of the families, gender and whether they were happy with the education, they were getting from their school made up for a significant difference, other socio-demographic features had no result in a significant difference. Mojgan et al., (2011) was detemined the relationship between state and trait anxiety with career indesicion of university students and relationship was reported positively (31). Also another study showed that the process of learning about global environmental problems had a significant impact on state anxiety levels of students (32). In present study similarly, state anxiety level was higher than trait anxiety level. The reason of this might be the examination of KPSS for career desicion end of the graduation year.

The effects of state anxiety levels on university students who take tennis exams measured in a research and it showed that state anxiety had a bad influence on applied tennis exam and this influence was greater on women than men (4). In a research focusing on anxiety and depression levels of a group of university students; female students compared with male students showed to have significantly higher anxiety levels (3). In the research, Pamuk et al., (16) analyzed state-trait anxiety levels of primary school teacher and have propounded that while state-trait anxiety levels of teacher candidates had no significant difference with regards to their marital status and academic success, between female teacher candidates and male teacher candidates had no significant differences. When analyzing open-ended questions they pointed out that teacher candidates were worried about not being able to find a job or assigned, failing at KPSS and expectations of family-community. In our research male student ratio was much greater than female students there have been no gender comparison.

253 candidates who were about to take a special talent exam in order to get in School of Physical Education and Sports examined according to few variables and the results showed that before taking the exam the candidates had average state anxiety level (56.86 \pm 7.76$)$. The results also showed that the fact that factors such as; candidates being male and under 19 years of age, it's being their first time taking the exam and them feeling inadequate with their preparations for the exam leveled up their anxiety (13). In present research, the gender rate differences analyzed but no significant differences found $(\mathrm{p}>0,05)$.

Depression and anxiety levels compared considering various factors. Bozkurt (3) noticed significant differences in depression levels of students depending on socio-economic positions of their families, the parental attitude, parents' perception of success, if they were studying the major they want or not, satisfaction level for their major and the reasons they took psychological consultation. $\mathrm{He}$ confirmed significant differences in a positive ratio between depression levels and trait anxiety levels of students and a negative one between their age and trait anxiety levels. A similar research was applied to 246 university students and results showed that while socio-demographic features such as; gender, monthly income of their families, their satisfaction or dissatisfaction with the education they were getting from their school caused significant differences, the other socio-demographic features had not result in any differences (21). Vitasari et al., (2010) investigated the relationship between academic performance and anxiety levels of the 205 students from faculty of engineering and the results showed that there was a significant correlation of high level anxiety and low academic performance among engineering students, with significant correlation $(\mathrm{p}=0.000)$ and the correlation coefficient is small with $\mathrm{r}=-.264(23)$.

\section{Conclusions}

The participants' general trait and state anxiety levels were examined and trait anxiety level was found as $40,18 \pm 8,32$ and state anxiety level as $61,19 \pm 11,02$. According to the academic year; there was statistically significant difference between $3^{\text {rd }}, 1^{\text {st }}$ year students and $4^{\text {th }}$ year students $(p<0,05)$. Particularly, it can be considered that $4^{\text {th }}$ year students' anxiety level affected by their career feelings and stress after graduation. Although there is no difference in anxiety levels according to the age factor, it can be thought that because of especially anxiety-enhancing factor emerge when the graduation approaches. There was no statistically significant difference in the level of state and trait anxiety according to the sections of the students (coaching, teaching and sport management $)(p>0,05)$. The fact that there was no difference of the anxiety levels according to the departments may be due to similar education. The results of this study, the future career and the vocational exams such as KPSS, which have an important place in terms of students' future, could be trained to cope with anxiety. Counseling guidance can be provided especially to students in different years.

\section{REFERENCES}

[1] Baştürk, R. (2007). Investigation of test anxiety levels of 
pre-service teachers taking civil servant selection examination. Firat University Journal of Social Science, 17(2), 163-176.

[2] Batumlu, D.Z.; Erden, M. (2007). The relationship between foreign language anxiety and English achievement of Y1ld1z Technical University School of foreign languages preparatory students. Journal of Theory and Practice in Education, 3(1), 24-38.

[3] Bozkurt, N. (2004). Bir grup üniversite öğrencisinin depresyon ve kaygı düzeyleri ile çeşitli değişkenler arasındaki ilişkiler. Eğitim ve Bilim, 29(133).

[4] Coşkun, K.; Şahan, A.; Erman, A. K. (2011). The effect of the state anxiety level on tennis exam performance in university students. Journal of Human Sciences, 8(1), 1121-1130.

[5] Ekici, G.; Kurt, H. (2012). Biyoloji öğretmen adaylarının kamu personeli seçme sınavına (kpss) yönelik kaygı ve saldırganlık düzeylerinin farklı değişkenlere göre incelenmesi. Eğitim ve Öğretim Araştırmaları Dergisi, 1(4), 294-308.

[6] Erözkan, A. (2011). Üniversite Öğrencilerinin sınav kaygısı ve başaçıkma davranışları. Sosyal ve Beşeri Bilimler Araştirmalari Dergisi, 1(12).

[7] Gündoğar, D.; Gül, S. S.; Uskun, E.; Demirci, S.; Keçeci, D. (2007). Üniversite öğrencilerinde yaşam doyumunu yordayan etkenlerin incelenmesi. Klinik Psikiyatri, 10(1), 14-27.

[8] Karaca, E. (2011). Öğretmen adaylarının kamu personeli seçme sınavı'na (KPSS) yönelik tutumları. Akademik Bakış Dergisi, 23, 1-18.

[9] Karasar, N. (1984). Bilimsel Araştırma Metodu. Ankara: Hacetepe Taş Kitapçılık.

[10] Kaya, M.; Varol, K. (2004). İlahiyat fakültesi öğrencilerinin durumluk-sürekli kaygi düzeyleri ve kaygi nedenleri (samsun örneği).

http://dergipark.ulakbim.gov.tr/omuifd/article/view/5000073 464/5000067723, Erişim tarihi 26.12.2016.

[11] Kula, K. Ş.; Saraç, T. (2016). Üniversite Öğrencilerinin Gelecek Kayg1si/The Future Anxiety of the University Students. Mustafa Kemal Üniversitesi Sosyal Bilimler Enstitüsü Dergisi, 13(33). Hacettepe Üniversitesi Eğitim Fakültesi Dergisi 18: 167- 176.

[12] Küçük, D. P. (2010). Müzik öğretmeni adaylarının sınav kaygısı, benlik saygısı ve çalgı başarıları arasındaki ilişkinin incelenmesi. Ahi Evran Üniversitesi Eğitim Fakültesi Dergisi, 11(3), 37-50.

[13] Lök, S.; İnce, A.; Lök, N. (2008). Beden Eğitimi Spor Yüksekokulu Özel Yetenek Sınavına Girecek Adayların Kaygı Durumlarının Bazı Değişkenler Açısından İncelenmesi. Niğde Üniversitesi, Beden Eğitimi ve Spor Bilimleri Dergisi, Niğde. 2(2).

[14] Özerkan, K. N. (2013). Üniversiteli Basketbolcularda Yarışma Öncesi Kaygı Düzeyiile Performans Arasındaki İlişki. İstanbul Üniversitesi, Spor Bilimleri Dergisi, 3, 4-6.

[15] Özyürek, A.; Demiray, K. (2011). Yurtta ve ailesi yanında kalan ortaöğretim öğrencilerinin kayg1 düzeylerinin. karşıllaştırılması. Doğuş Üniversitesi Dergisi, 11(2), 247-256.
[16] Pamuk, Y.; Hamurcu, H.; Armağan, B. (2014). Sınıf Öğretmeni Adaylarının Durumlukve Sürekli Kayg1 Düzeylerinin İncelenmesi (İzmir-Buca Örneği). Journal of Faculty of Education, 3(2), 293-316.

[17] Sezgin, F.; Duran, E. (2011). Kamu Personeli Seçme Sınavı'nın (KPSS) öğretmen adaylarının akademik ve sosyal yașantılarına yansımaları. Türkiye Sosyal Araștırmalar Dergisi, 153(153).

[18] Şahin, İ.; Zoraloğlu, Y. R.; Fırat, N. Ş. (2011). Üniversite öğrencilerinin yaşam amaçları, eğitsel hedefleri üniversite öğreniminden beklentileri ve memnuniyet durumları. Kuram ve Uygulamada Egitim Yönetimi Dergisi, 17(3), 429-452.

[19] Spielberger, C. D. (1972). Anxiety as an emotional state. Anxiety-Current trends and theory. New York: Academic Press, S.24-49.

[1] Öner, N. (1997). Durumluluk Sürekli Kayg1 Envanterinin Türk Toplumunda Geçerliliği. Doçentlik Tezi, Hacettepe Üniversitesi Sosyal Bilimler Enstitüsü, Ankara.

[20] Yılmaz, İ. A.; Dursun, S.; Güzeler, E. G.; Pektaş, K. (2014). Üniversite öğrencilerinin kaygi düzeyinin belirlenmesi: bir örnek çalişma. EJOVOC: Electronic Journal of Vocational Colleges, 4(4).

[21] Yokuş, T. (2012). The relationship between the state-trait anxiety levels and the academic achievement of music teacher candidates. International Online Journal of Primary Education (IOJPE) ISSN: 1300-915X,2(1).

[22] Vitasaria P,Abdul Wahabb MN, Ahmad Othmanc, Herawand T, Sinnaduraie SK (2010)The Relationship between Study Anxiety and Academic Performance among Engineering Students, Procedia Social and Behavioral Sciences 8 490497.

[23] Lama M. Al-Qaisy (2011), The relation of depression and anxiety in academic achievement among group of university students, International Journal of Psychology and Counselling Vol. 3(5), pp. 96-100.

[24] Rand J, Poornaghi Z (2012)The Relationship Between State-Trait Anxiety and Students' Sense of Social Self-Efficacy, World Applied Sciences Journal 20 (3): 395-400.

[25] Remedios E. Basco and Melanio T. Olea (2013) Correlation between Anxiety Level and Academic, Performance of BS Biology Freshmen Students, International Journal of Educational Research and Technology, Volume 4 [1] March 2013: $97-103$.

[26] Gökçe, T. ve Dündar, C., (2008). "Samsun Ruh ve Sinir Hastalıkları Hastanesi'nde Çalışan Hekim ve Hemşirelerde Şiddete Maruziyet Sıklı̆̆ ve Kaygı Düzeylerine Etkisi”, İnönü Üniversitesi Tıp Fakültesi Dergisi, S.15, C.1, ss.25-28.

[27] Palti, C. (2012) Üniversiteye Hazırlanan Lise Son Sınıf Öğrencilerinde Yükseköğretime Geçiş Sınavı Öncesi Ve Sonrasında Benlik Saygısı, Sinav Kaygısı Ve Durumluk Sürekli Kayg1 Düzeyleri, Yüksek Lisans Tezi, İstanbul Üniversitesi Sosyal Bilimler Enstitüsü, İstanbul.

[28] Öner, N., Comte, A. L. (1983) Durumluk Kayg1 Envanteri El Kitabı. Bogaziçi Üniversitesi Yayınları, no: 333, İstanbul. s.6. 
[29] Mcknight, J., Mcknight. M., A., (2012) Gender and Anxiety: A Comparison of Student Anxiety Levels in Face-to-Face and Video Conferencing Courses, Creative Education Vol.3, No.1, 92-95.

[30] Mojgan, F., N., Abd. r., Kadir, Soheil, S., (2011), Relationship between State and Trait Anxiety with Career Indecision of Undergraduate Students International Education Studies Vol. 4, No. 3; August.
[31] Oluk, S., Özüredi, Ö., Sakac1, T., (2009) Determination Of State-Trait Anxiety Levels Of University Students During The Learning Process Of Global Environmental Problems, Us-China Education Review Volume 6, No.1, ISSN 1548-6613, USA. 